Hubris and Its Impact on Captain Ahab of Herman Melville's Moby-Dick

Abdo Ibrahim Jarjanazi

Syria/ Homs

00963933366879

abdo-edu@ hotmail.com

Abstract

Hubristic characters, in Greek mythology and in later eras, have been looked at negatively. Once a hubristic character emerges, that would provoke nemesis. Consequently, society would punish him/her since she/he allegedly challenges the gods, ignoring warnings and laws of society, and that would present him/her as someone rude and challenging the norms. Accordingly, such a hubristic character would eventually face moral, spiritual, and physical downfall. However, it seems that presenting a hubristic character in Greek mythology and in later eras in such a negative way is a mere fallacy. In fact, effective pride springs from certainty and over-confidence. Consequently, in demonizing effectively proud characters, they unconsciously impede and restrict human abilities and passions from unleashing against the negatively effective forces of external nature and internal human one, which need great toil to endure.

This paper attempts to, first, explore and study the actions and psyche of the proud Captain Ahab of Herman Melville's Moby-Dick. Its second objective is to study the importance of pride and its great effects on the psyche and behavior of the above mentioned hero and on astonishingly shaping the whole course of evolution of incidents. Third, it aims at showing the noble human passions and abilities propelled by his effective pride where he employs them against the forces of nature. Fourth, it also aims at showing his individuality against the forces of nature and how his effective pride mediates in his inner impulses as an organizer, pushing them forward rather than backward. Accordingly, his pride emerges as an effective force challenging the forces of nature. Captain Ahab appears proud of his abilities and passions. In other words, he well recognizes that he is determined, courageous, daring, fearless, and tenacious. Finally, it concludes that effectively pushing pride foregrounds the captain as extremely effective, influential, and inspiring. He prides himself on the positive attributes which he has, and this eventually makes him infinitely and imperiously assertive, insistent, and equivalent to the forces of external nature where he becomes, in spite of his death, not only a hero but also an inspiring one.

Key words: Hubris- Tenacity- Determination- Do-or-die attitude 


\section{Hubris and Its Impact on Captain Ahab of Herman Melville's Moby-Dick}

It is very important not to undermine the concept that this great universe and its essence are not easy to grasp, and humans need great efforts to endure its hardships. Humans' understanding and perspective of the universe vary. Some people think that life is a gift from God, so Man has to live peacefully and humbly, acting and behaving moderately with the surrounding nature, and she/he should not transgress the limits of human beings. Others think that the universe came to existence by accident, and Man is the center of the universe, because she/he is the only supreme and overpowering creature in this universe. Therefore, human beings have to investigate and prove their existence and try to reach a high position in life. Accordingly, it is, in both cases, a big challenge for human beings to endure the hardships and obstacles of life. There is no doubt that life is full of mysteries, ambiguities, obstacles, hardships, knowledge, despair, hopes, dreams, and pleasures. People by instinct, as Nietzsche suggests ${ }^{1}$, strive for absolute knowledge and pleasure or displeasure, because this is why humans are born in life. In order to accomplish that, they have to encounter hardships, obstacles, despair, hopes, and maybe success or failure. In fact, human beings are born immature, so they have to journey battling and undergoing the ups and downs of life in order to be mature. In this case, Man is regarded as a rootless human being and the outcome of circumstances, belonging not to the human race but to the environment and circumstances in which she/he lives. Man becomes strong because nature endows him/her with strength; she/he becomes weak because nature or the environment imposes this on him/her. Accordingly, Man is always in a continuous struggle with the environment in order to strike a balance between the difficult environment and his/her needs and desires. When life sometimes seems difficult to a human being, she/he may be drifted far away from the norms in order to find a new path or identity through which she/he can adapt with the surrounding environment. Because life is sometimes difficult and needs great effort to endure, innocence sometimes turns into brutality, hesitancy to determination, and sometimes over-determination. The basic problem that Man encounters is the inclination to which way she/he should follow. In that case, Man becomes unstable, not knowing how to fully take

\footnotetext{
'Nietzsche thinks that there is an effective force existing inside human beings by which they try to reach the elitist point in life. This force (power, or will to power) shows that "pleasure and displeasure can only be means in the course of events: the question remains whether we are at all able to see the "meaning", "the aim," whether the question of meaninglessness or its opposite is not insoluble to us" (Nietzsche 23-24).
} 
resolute decisions, but when pride intervenes, all decisions are settled as we shall see later with Captain Ahab.

The sea, for nautical questers, is always looked at as bizarre, mysterious, attractive, full of adventures, obscure, and more importantly dangerous. Although it is dangerous and mysterious, unique questers, such as Melville's Captain Ahab, dare to sail, investigate, and find their new identities. In fact, a sea-journey "represent[s] the urge to be wandering forward into new territories, or questing far away from society for the holy grail of raw experience" (Hamad 5). Therefore, since Man is ambitious by nature, it is his/her instinct that requires him/her to uncover the secrets of the mysterious sea, and unique questers are "never lost at the sea [because] it is a long island" (Hemingway 75). By contemplating the scene of the sea, it seems that it is dangerous, and its voice is inviting, seductive, and attractive to those questers to go, discover, and eventually find out their identities. In this regard, it is vital to mention Kate Chopin's notion about the sea. She says:

The voice of the sea is seductive; never ceasing, whispering, clamoring, murmuring, inviting the soul to wander for a spell in abysses of solitude; to lose itself in mazes of inward contemplation. The voice of the sea speaks to the soul. This touch of the sea is sensuous, enfolding the body in its soft, close embrace. (13)

When people investigate the universe, they encounter many clashes with the magnitude of the universe. There are many forms of clashes in this great universe. For example, both waves of the sea and stones of the beach clash with each other on shore. None of them is ready to surrender. Waves will never show any sign of withdrawal or stoppage. Likewise, stones consistently try not to be smashed. Such a clash is a nature - nature one. However, Man is, to some extent, physically weak, and a clash between Man and nature most often results in Man's destruction, if not in his/her defeat. This clash is destined to continue, but nature or the environment is physically stronger than Man even though Man has great physical strength. Therefore, because nature is full of mysteries, Man is involved in a clash against the unknown. Such a clash generates knowledge, and this actually results in the benefits of human beings. In order to survive and adapt with their lives, human beings try to investigate and discover more secrets of this great universe, but nature does not easily reveal its hidden secrets to any one unless she/he has shown some special abilities and qualities, such as human pride and self-esteem, which distinguish him/her from other ordinary people. Accordingly, pertinent to determination, strong will, self-esteem, and pride are amongst the distinguished qualities Man has to manoeuver. What is crucial here when the clash occurs is that those who are determined 
and effectively hubristic recognize that they must win the battle; otherwise, that would fragment their ego and result eventually in their physical and more importantly spiritual downfall, as we shall see later with Captain Ahab.

Humans are made of paradoxes: they sometimes appear good, bad, determined, hesitant, fearful, courageous, proud, or humble. "The mariner- quester's ability to resolve the paradoxical meaning inherent in his quest determines the ultimate value voyaging has for him" (Hamad 7). Captain Ahab, out of his effective hubris, resolves the paradoxes and tries not to be at the back or even in the middle row but at the front one. Hubristic heroes choose to be effective, influential, powerful, and challenging especially when they try to challenge the bounds of the norms and society. Therefore, there is no harm actually in "stand[ing] out of the crowd", having an "outsized ambition" or "toppling the status quo when it is not working" (Khuon) ${ }^{2}$. In addition, hubris, in the Modern Age, is not believed to be negative since it gives the feeling that "one has penetrated into the deepest mysteries of being, and plumbed the most abysmal errors of the dominant civilization" (Beiner 122). Humans are physically and mentally designed to investigate and discover facts. In order to be prominent, one has to be excessively proud of himself/herself for the positive attributes she/he has in order to go forward, as is the case of Captain Ahab. Moreover, effective hubris makes heroes take courageous and daring steps making them imperious and influential. Hubristic people are more investigating, searching, discovering, questing, curious, inquiring, considering, reconsidering, and commanding. They also epitomize the strongest, elitist, the most leading light, and the best of others because "they are disagreeable people ... propel[ling] the human race forward with their uncompromising vision. And they will pull the rest of us with them kicking and screaming if they have to" (Khuon). This may actually provide positive results because this pushes those who are slothful to work more and trust themselves greatly. Self-trust in people varies from one another, and those who are hubristic definitely have great self-confidence, trust, and high selfesteem. That is why they become, for those who do not have self-trust, a great example to follow.

Captain Ahab of Melville's Moby-Dick is foregrounded by Melville to the crew and other captains of other ships as an effectively hubristic leader whose thoughts and behavior cannot be easily predicted. This captain actually seems to have a tremendous human energy which drags him far away into the depth of the ocean. Melville

\footnotetext{
'Tony Khuon wrote an article entitled "When Hubris Is a Good Thing". This article does not have page numbers. The full bibliographic information is in the bibliography.
} 
artistically manipulates the captain's strange behavior and thoughts to obliquely elevate the concept of excessiveness over the hardships of nature that restrict human beings' progress. Melville praises the captain's fearlessness, over-confidence, uniqueness, and charisma saying:

I don't know exactly what's the matter with him; but he keeps close inside the house; a sort of sick, and yet he don't look so. In fact, he ain't sick .... He's a queer man, Captain Ahab ... but a good one. Oh, thou'lt like him well enough; no fear, no fear. He's a grand, ungodly, god-like man, Captain Ahab; doesn't speak much; but, when he does speak, then you may well listen. Mark ye, be forewarned; Ahab's above the common; Ahab's been in colleges, as well as 'mong the cannibals; been used to deeper wonders than the waves; fixed his fiery lance in mightier, stranger foes than whales. His lance! aye, the keenest and the surest that out of all our isle! Oh! he ain't Captain Bildad; no, and he ain't Captain Peleg; he's Ahab, boy; and Ahab of old, thou knowest, was a crowned king! (75)

Form this vivid portrayal which is taken from Moby-Dick ${ }^{3}$ about the great Captain Ahab, he seems to embody the real meaning of greatness, overpower, heroism, leadership, education, inspiration, and uniqueness. Captain Ahab is the captain of the Pequod ${ }^{4}$ whose unfathomable behavior confuses the crew including the sole survivor of the shipwreck, Ishmael. Captain Ahab loses his leg in one of the pursuits on the sea after Moby-Dick. By taking his leg, his excessive pride and dignity as a great leader and whaler are taken along with the whale. Afterwards, he makes a substitutional leg made of whales' bones and embarks on a sea-journey to tenaciously bring Moby-Dick down and restore his damaged pride and reputation since he is a great whaler and captain whose life is replete with success, and a captain's dignity cannot stay stable if his pride is at stake. Eugene Sadler-Smith arguers that "hubris is known to develop when a leader has been in a position of significant power and a record of prior successes" (12). Killing Moby-Dick hubristically becomes the axis of his nautical quest, for the whale sounds mysterious to Captain Ahab, and Captain Ahab's dignity and uniqueness necessitate unveiling such a mystery. When the whale cuts Captain Ahab's leg, he loses his pride and free will. Accordingly, Captain Ahab's pursuit is not seemingly for material purposes but for spiritual ones. He wants to restore his sacked pride and self as a great sea captain and a whaler. His taken pride pushes him to say, "What I've dared, I've willed; and what I've

\footnotetext{
This novel is sometimes called The Whale. Moby-Dick is the name of the white whale that Captain Ahab is extremely eager to kill and pin down.

'It is a kind of a whaling vessel which has a savage appearance. It is ornamented with the bones and teeth of the sperm whales.
} 
willed, I'll do!" (Melville ${ }^{5}$ 142). Although he has one leg, he wants to prove that he is able to go and achieve what he aims at by fighting what is great. It seems explicitly that the motive behind Captain Ahab's nautical quest for the whale is to avenge himself because the whale severs his leg, but it is implicitly full of the real meanings of Man's significance, unveiling truth, self-assertion, and overpowering ability in this universe. In addition, Captain Ahab's quest on the sea epitomizes the real meaning of heroism, courage, and challenge in his pursuit after Moby-Dick who sounds frightening to other whalers. His effective hubris, through his quest, makes him a respectable and a true leader because he insists on having his aim heedless of the cost. Because Captain Ahab does not hubristically heed the cost of the consequences where hardships of nature sometimes necessitate a serious clash with Man, this drives Peter B. High to classify him as a transcendentalist: "Man's relationship with nature transcends the idea of usefulness" (43). Such transcendence is for satisfying the inner desires and needs which lie in self-assertion and fighting the great. Moreover, the pursuit towards Moby-Dick is full of values and knowledge. He considers the whale to be a destination of ultimate truth that should be searched for, found out, and deciphered. Therefore, such nautical journeys, full of values, force High again to praise Melville's heroes' nautical journeys saying that they "are always searches for the truth" (52). This truth, for Captain Ahab, is embodied in the white body of Moby-Dick upon which Captain Ahab jumps in order to kill and pin him down and in the depth of the ocean where he finally drowns. Therefore, this is in itself a noble pursuit because Captain "Ahab's hunger for metaphysical truth [and] knowledge [is] not only as a source of despair but also as a source of creativity" (Fluck 211). His tenacious, willful, and hubristic spirit causes his death at the end in a scene that is full of the real meaning of heroism and manhood. Not only does he die but also all the crew except for the narrator, Ishmael. Such a great battle with the giant Moby-Dick elucidates an indomitable and hubristic spirit which is rarely found in ordinary people.

Captain Ahab is armed with too much pride that keeps him eminent and influential from the beginning of his quest till the end. Balancing gingerly on one leg, the human pride and strong will to achieve an aim show that they are unparalleled to the forces of nature incarnated in Moby-Dick. They prove effective and influential and become a perfect means to use in order not to surrender to recklessness or idleness. Furthermore, Captain Ahab inspires others

"All quotations related to "Melville" in this paper are taken from the novel Moby-Dick by Herman Melville. 
that by being hard-working, proud, strong, insistent, and overconfident, the secrets of this enormous universe may become accessible. He well knows that truth lies there in the depth of the ocean. That is why he insistently and hubristically journeys into the depth of the ocean. Accordingly, his effective hubris, heroic actions, insistence, and encouragement on the sea make the crew recognize that "in landlessness alone resides highest truth" (Melville 95). Such a high truth, according to Captain Ahab, should be chased in the globe whatever the costs are. Moreover, if humans encounter a dead end, they should not give up but rise again as a phoenix because truth may be found through the way towards the dead end. Melville elevates the pursuit after Moby-Dick whatever its results are, saying that "in the pursuit of those far mysteries we dream of" resides the clue. "While chasing such over this round globe", he affirms, "they either lead us on in barren mazes or midway leave us whelmed" (197). In both cases, knowledge would hover over questers. Accordingly, they should consider and reconsider things until they are well absorbed and crystal clear. Only after Man has a clear destination and purpose does progress start to emerge. Captain Ahab is eager to hubristically draw a clear destination for his purpose which is attaining the far-reaching truth when "he rises to a staggering hubris as he shouts, "Who is over me? Truth hath no confines" (Spark 311).

Captain Ahab's journey towards the white and enormous whale represents the quest for this enormous universe in order to search, quest, find, find out, fully grasp, and finally imbibe. By striking in the body of the whale, he metaphorically strikes the huge and covering mask of the universe to unveil its secrets. Many critics such as Clare L. Spark and George Cotkin argue that Captain Ahab runs after the whale because he wants to take revenge on that whale since he cuts his leg. Cotkin says that Captain Ahab is eager "for revenge about a lost limb" (Dive Deeper 242) ${ }^{6}$, whereas Spark suggests that Captain Ahab "indulges his passion for revenge against a mere beast" (152), but it seems that Cotkin and Spark may not be accurate in analyzing the real motive of Captain Ahab towards the whale where they tend to classify it as a desire for vengeance. In fact, Captain "Ahab's been in colleges" (Melville 75). He is an educated leader and too much greater than thinking in such a naïve way. He never thinks of taking revenge on a merely brute animal. Because a great Captain such as Captain

\footnotetext{
'George Cotkin wrote a book entitled Dive Deeper: Journeys with Moby-Dick. In this book, before he analyzes the actions of the hubristic Captain Ahab, he mentions some of the great literary figures' perceptions about Moby-Dick. Such figures are the following: Hart Crane, Lowry Nelson, Jr., Van Wyck Brooks, D. H. Lawrence, Archibald MacLeish, Joseph Conrad, Jony Kushner, C.L.R. James, William Faulkner, and Albert Camus. The latter critics' views will be used in the paper cited in George Cotkin's Dive Deeper: Journeys with Moby-Dick.
} 
Ahab "is above the common" (75) and "is lord over the level loadstone" (409), he does not think in such a way since his ambitions are elite and sometimes unfathomable by ordinary people, and this is the quality of unique people. His quest's axis is to assert and restore, although he has one leg which is in itself a challenge to lead, the human pride and dignity that are taken from him by Moby-Dick. The animal actually represents, for Captain Ahab, a destination in which truth and human victory lie. Moby-Dick also represents the great mysterious universe because he is as enormous as the concept of the great and huge universe. Hart Crane describes "the Whale [as] a metaphysical image of the universe" (Cotkin, Dive Deeper 9). Because the whale is extremely enormous, it is full of mysteries, ambiguities, truth, and reality. Accordingly, there is something in that whale that has a seductive and inviting aura, so it represents something mysterious and hidden for Captain Ahab. The charismatic color, name and huge body of the whale impress William Faulkner who says that "there's magic in the very word. A White Whale. White is a grand word, like a crash of massed trumpets; and leviathan himself has a kind of placid blundering majesty in his name" (197). Such charismatic features characterized in the whale attract Captain Ahab to a challenging and noble war full of suspense. In fact, human beings' job in life is to nobly go, challenge, unveil, and find out what is hidden. That is why they are born in this universe. The sound of the phrase "Round the world!", asserts Melville, becomes enigmatic to the hubristic Captain Ahab where he contemplates how "there is much in that sound to inspire proud feelings". He well recognizes that "that circumnavigation conduct" would breed "numberless perils", and this may or may not be in vein because that may eventually bring him "to the very point whence [he] started". Although the ambitious Captain realizes that life is circular, he insists on unveiling the veiling by magnificently and incredibly inquiring if the "world" were "an endless plain, and by sailing eastward we could for ever reach new distances, and discover sights more sweet and strange" (Melville 197). Therefore, Captain Ahab, as a great and hubristic leader and quester, is honorably covetous to nobly investigate and bring that whale down and hubristically make him lie under the human dominance regardless of the results.

No one is a match with Captain Ahab even the other leaders, Captain Peleg, Captain Bildad, or Captain Boomer ${ }^{7}$. The latter has a confrontation with the same whale, Moby-Dick, who cuts again the captain's arm. What is important here is that that captain is an ordinary one who gets afraid of Moby-Dick and is never willing to go

${ }^{\vee}$ These are the captains of other whaling ships. 
or discover the essence of that whale. On the contrary, Captain Ahab is eagerly pushed by his monomania, effective hubris, and his inner great qualities to discard the grand Moby-Dick from the domain of the sea, for there is no power equivalent to the grand Captain Ahab. Captain Boomer, the captain of Samuel Enderby ${ }^{8}$, thinks that it is not feasible to run after the great whale although he considers killing the whale brings much glory and oil. He addresses Captain Ahab when they discuss the case of the whale that "there would be great glory in killing him, I know that; and there is a ship-load of precious sperm in him, but lurk ye, he's best let alone; don't you think so, Captain? glancing at the ivory leg" of Captain Ahab (Melville 354). Captain Ahab does not hubristically heed Captain Boomer's warnings of avoiding confrontation with the huge white whale. Instead, he becomes monomaniacally industrious to find out ways and techniques to hubristically put Moby-Dick under his dominance. In fact, the motive of Captain Boomer is completely different from that of Captain Ahab. Those two captains represent two types of people. One type is hubristically determined and fiery while the other is not, seeking a safe and peaceful way of living. Captain Boomer considers Moby-Dick cursed, and he "is best let alone" because such an "accursed thing is not always what least allures" (354). By comparing and contrasting Captain Ahab to Captain Boomer, this actually manifests the excellence of Captain Ahab to Captain Boomer. Captain Boomer is not mentioned so often and may not be liked by readers as a captain. He represents ordinary captains without being charismatic or daring, which are essential qualities for sea-captains. In fact, being excessively judicious, calculating, and sagacious can be sometimes boring and dull; a sea-captain should be daring, dauntless, bold, and audacious in order to discard fear from his crew. Captain Boomer stops pursuing since Moby-Dick severs his arm unlike Captain Ahab who is hubristically daring, over-confident, and insatiable to continue forward heedless of the consequences. Furthermore, Captain Ahab involves, out of his hubris, himself in perils, in what has an aura of mystery, and in what causes phobia to other whalers. He is ready to put himself in jeopardy in order to affirm his manliness, manhood, and magnificence in life. Therefore, he shows his greatness as a human being who is the only supreme power to the tangible objects of nature. He tenaciously and hubristically shows that he can do it and kill that leviathan. His tenacity, charisma, effective hubris, and "fine, loose [and] chivalrous attitude ... when drawing near his prey" force the crew, asserts Melville, to be like him when "the three mates stood up proudly, occasionally backing the after oarsman with an exhilarating

\footnotetext{
It is another whaling vessel led by Captain Boomer.
} 
cry of ... sail over him!” (286-87). His taken dignity and reputation are very precious for him, so he is resolved not to be himself until his consideration is brought back. Heedless of the consequences, the hubristic captain is ready to honorably "sacrifice all mortal interests to all that one passion" (176). Such craziness and monomania in his behavior force the pen of Larzer Ziff to write that Captain "Ahab challenges the laws of the creation and dares to steal divine thunder in order to shape it to his end" (xvi). This is not weird to Captain Ahab because, as Captain Bildad" describes him, "he is a grand, unglodly, god-like man" and "has his humanities" (Melville 75-76). Captain Ahab is described as crazy. In fact, he is not crazy but crazed with his aim which is pinning the whale down. "The people who are crazy enough to think they can change the world are the ones who do" (Isaacson 4). This actually foregrounds him to the crew and other sea captains. He strives to show that Man's ability has no limits by asserting itself against the calamities of nature. If human beings do not overcome the forces of nature, they will overcome them. In other words, if they do not show that they are very strong and determined, these forces will bring them down.

The Pequod actually symbolizes a small society, and the people inside it represent every sector of that society. Some are willing; others remain passive, while the rest are reluctant. Each one of the crew has his own type of quest. Fluck takes the chance to describe the ship saying that "the usefulness of the Pequod to function as metaphor for a new society lies in the possibility it offers to bring together a wide range of different regions, races, and cultures". Fluck puts this idea forward saying that "Ishmael's decision to go to sea is thus not an escape from society but its reconstitution on a new basis" (210). Some men, in the ship, are adventurers especially Queequeg who wants to make some discoveries and learn about Christianity. Queequeg is a black man who is greatly affected by Captain Ahab's charisma and effective hubris. He expresses his full willingness to proudly follow the captain even to death. He addresses the captain: "Oh, sir, ... rivet these two hands together; the black one with the white, for I will not let this go". "Oh, boy, nor will I thee, unless I should thereby drag thee to worse horrors than are here", (Melville 412) replies Captain Ahab. Then the captain continues his philosophical ideas about Man's relation to the indifferent universe saying: "Ye believers in gods all goodness, and in man all ill, lo you! see the omniscient gods oblivious of suffering man; and man, though idiotic, and knowing not what he does, yet full of the sweet things of love and gratitude". Afterwards,

${ }^{9}$ Captain Bildad is the leader of another whaling vessel and a colleague to Captain Ahab in the whaling profession. 
the captain auspiciously tells the man that he "feel[s] prouder leading [him] by [his] black hand, than though [he] grasped an Emperor's!" (412). Being charismatic, he succeeds in leading the crew to his aim since he emerges as a great man that other men are never like him. In this ship which represents society, there are whalers who are hesitant and humble, and there are others who are not. There are whalers who are afraid to act. Unlike those men, it is Captain Ahab who is unique and dissimilar to others. In fact, it is humans' own choice when they want to go and elevate themselves. It is their choices that draw right and different paths to their lives. Differing from others, Captain Ahab draws a uniquely marked path which makes him a hero whose behavior teaches others the meaning of free will, insistence, and determination. Such monomania and effective hubris actually force Fluck's pen to write that "his obsessive insistence creates a remarkable intensity which distinguishes Ahab from all other characters and gives him a heroic dimension" (209).

The concept of the precise meaning of death and faith is of a great importance in light of Captain Ahab's pursuit and aim. Before the sea journey sets off, Father Mapple's sermon preaches in the church while standing on the pulpit similar to the ship masthead about the blackness of darkness, suggesting impliedly that evil is impenetrable and cannot be grasped by human beings. This entails that Captain Ahab and the crew should not try to involve themselves in danger or with the devil; otherwise, they must be prepared to encounter their death with faith. Cotkin supports Captain Ahab's existential attitude and encourages Man for this saying:

Mapple's well-stitched cloth of faith conceals a world without meaning, more horrifying, without salvation. In this shock of recognition, man retains only an existential striving to define himself, to create meaning. Like Ahab, man must create his own compass; out of a common needle he can make one of his own, that will point as true as any. (Existential America 19)

The existentialist Captain Ahab tailors the cloth of Mapple and thinks of weaving another cloth that he himself stitches according to his needs and desires. Such well-stitched cloth embodied in individuality and monomania forms the philosophy of Captain Ahab who thinks that Man better tries because everything can change through the course of life. Well-stitched cloth of Father Mapple means nothing to the existentialist Captain Ahab who looks askance at everything except for himself. In fact, things change and sometimes have opposite meanings. Death, in fact, means death, but sometimes death comes to mean life. For example, Queequeg makes a coffin in order to be put in because he predicts his death, so it becomes the symbol of death. The same coffin which is the symbol of death comes to mean at 
the end of the sea-journey a symbol of life when the only survivor, Ishmael, floats on after Moby-Dick rams The Pequod and makes it sink. Similarly, it is true that Captain Ahab dies at the end, but death does not mean death here because it does not mean that he is defeated since the way he dies and the way he walks towards his death foreground him as a hero and make him immortal in others' mentalities, particularly the sole survivor, Ishmael. His death immortalizes him since he runs after a noble ${ }^{10}$ aim and hubristically fights what is great and dangerous. Therefore, the way he dies is a perfect epitome of heroism. Of course, he is effectively hubristic; this act of effective hubris causes tragically his death but not defeat since his "quest for metaphysical knowledge generates and drives the narrative ... [and] raises him to the level of tragic hero on the model of Shakespeare's Macbeth and King Lear" (Fluck 209). He, out of his effective hubris, does not heed the mortal danger, recognizing confidently that he can win over nature represented by Moby-Dick. In fact, Captain Ahab's daring steps towards recognizing the blackness of darkness must be taken into account although this takes him too far. Accordingly, how would the blackness of darkness be lighted unless humans go there and light it up? It is humans' job in life to search for the unknown to make it known and to go to the heart of darkness to light it and make it bright for other generations to continue the mission of discovery and questing in the mysterious universe. The blackness of darkness, asserts Melville, which Captain Ahab is eager to light up lurks "in that howling infinite" (95) of the sea where "in [its] eternal tossings the wild fowl finds his only rest". Captain Ahab expresses his indebtedness to the sea where he admits that he is "born of earth, yet suckled by the sea". That noble captain is faithful to the place where he works in, and this is in itself nobility which the captain should be respected for. "Though hill and valley mothered" him, the sea "billows are [his] foster-brothers!" (394). Accordingly, questing towards the unknown is, in spite of danger and death, not an ordinary quest but a noble one although it leads the captain to death. It seems that the captain does not care about death where "old age is wakeful", asserts Melville, "the longer linked with life, the less man has to do with aught that looks like death" (108). Therefore, since humans are all mortal, running nobly and honorably towards death "in that howling infinite" drives Bacon to befriend the concept of death in his "An Essay on Death" saying: "death is a friend of ours; and he that is not ready to entertain him is not at home" (255).

It seems that Ishmael represents every humble man in this universe, but Captain Ahab does not actually represent every man

It is noble because the captain quests within the domain of his job and profession as a whaler. 
since he differs from thousands of others where he is charismatic in a way that makes others willingly follow him, and this is the real meaning of leadership. "The dialectical relationship between Ishmael and [Captain] Ahab is the central structural principle of the quest" (Fluck 211). Moreover, such implied comparison by Melville between Ishmael and Captain Ahab seems to foreground the latter to the former. Melville here skillfully shows his ambivalence through a continuous comparison between the views of the two characters to show the difference between two types of people. Fluck says:

The basis for the novel's effect, or, more precisely, its implied theory of effect, can be seen in a skillful movement back and forth between [Captain] Ahab's heroic quest for meaning and Ishmael's playful acceptance of the endless supplementarity of meaning, in a carefully crafted strategy of changing perspectives which alternately provides and withdraws authority in order not to become arrested in either one of these perspectives. (211)

It seems that Fluck tries to say that readers are lost between the two characters. Some may tend to support Ishmael's spirit which brings safety and humbleness. Others may tend to support Captain Ahab's spirit which is full of adventure and hubris. Fluck says:

In [Captain] Ahab's uncompromising individualism and Ishmael's attempt to escape his own eccentric individuality by submerging himself into an egalitarian community of sailors, two liberal versions of the relation between individual and society are confronted with each other in order to articulate a third, utopian one which emerges from a narrative technique of changing perspectives, that is, from an aesthetic mode of communication. (211)

This third utopian reader Fluck expects to emerge may seem again lost. It is only Captain Ahab who appears eminent and influential where the harsh environment necessitates this. He, by his charismatic personality, boosts the morale of the crew and makes them recognize that nothing is impossible. He again makes them believe more in their abilities and strength to challenge the forces of nature.

Any clash between Man and nature results absolutely in Man's benefit. In other words, any clash between Man and nature brings knowledge and benefits for the one who dares to make the clash and for the others who watch the clash. Unique people, such as Captain Ahab, are the ones who make severe and challenging clashes that ordinary people do not dare to. Therefore, secrets and resources of nature do not deliver themselves easily to humans unless they proudly exert great efforts because "dignity and danger go hand and hand; till you get to be Captain, the higher you rise the harder you toil" (Melville 380). Furthermore, clashes may not be always dangerous. It is important not to forget that nothing exists in this universe beyond humans' abilities. Everything in nature is subject to rules and laws, so 
Man is the only supreme power in the universe in dealing with tangible objects of nature. In other words, by applying rules and laws, humans can overcome any tangible objects in the universe. Therefore, humans' abilities and capabilities can overcome and unveil the mysteries of the universe. Moreover, the forces and challenges of life are boldly encountered when Captain Ahab is armed with too much pride that does not permit surrender or withdrawal. Instead, it makes the way smoother because the too much pride of Captain Ahab summons other great human attributes such as determination, overdetermination, insistence, courage, self-esteem, and dignity. His excessive pride does not also allow negative impulses to assert themselves inside his psyche.

On the giant body of the whale are knowledge and mysteries which should be unveiled and availed from. On the body of the whale lies the whiteness which is very seductive to the quester, Captain Ahab. There again lies greatness of the whale which again symbolizes greatness and mystery of nature. This nature forcefully tries to take the human attributes such as determination, toil, struggle, and tolerance. Humans give such attributes to the sea in order to allow them go deep into the ocean in order to uncover what is covered. This clash between Man and nature is characterized as a giving and taking one. Therefore, those who are excessively proud, charismatic, and determined are distinguished from others who are not since they possess top qualities. In facts, the top things impress Melville when he says that "there's something ever egotistical in mountain-tops and towers, and all other grand lofty things". He links these lofty things to Captain Ahab, describing him as "the firm tower, that is Ahab; the volcano, that is Ahab; the courageous, the undaunted, and the victorious". Melville greatly elevates the mysterious captain to the level of the mysteries of the globe which need great toil to make the ungraspable graspable. For example, the concept of the systematic movement of the earth around the sun is a mystery and needs to be unveiled. "This coined sun wears a ruddy face [and] ... enters the sign of storms, the equinox! and but six months before he ${ }^{11}$ wheeled out of a former equinox at Aries! From storm to storm". Within these unsolved mysteries of nature, assures Melville, emerges the dilemma of Captain Ahab who is "born on throes", and he accordingly "should live in pains and die in pangs", trying "to work on" and solve the "stout stuff for woe". However, taking greatly the magnitude of nature into consideration, it seems, affirms Melville, that "great pains, small gains [are] for those who ask the world to solve them; it cannot solve itself" (346). Nature,

" "He" refers to the movement of the earth which results in day and night and in the seasons of the year. 
including the sea, should have its share of humans' efforts, toil, patience, and determination in order to give its gifts in return. Therefore, humans should not give up their goals whatever the challenges are even though the answers to the mysteries of the world are not answered yet. Accordingly, the human continuous toil and persistence are the means to reach a goal. Moby-Dick is known for his danger and enormous dimensions since he claims many whalers' lives. It is Captain Ahab's dignity, toil, persistence, and effective hubris that require him not to surrender or withdraw. He pins a golden doubloon on the mast for the first whaler to spot Moby-Dick. This is actually what real leaders are expected to do when they build their crew's morale. Certain sayings and actions, asserts Melville, are used by the captain as "certain prudential motives, whose object might have been to revive the spirits of his crew by ... his ... skill, in a matter so wondrous"(409). He gives the golden doubloon for the one who spots Moby-Dick. After that, he tells the crew that when they catch the whale, they will have his share of the whales' whole profits. He spends seven hours at night under the light of the moon watching out for Moby-Dick. This is a perfect example of those who set for themselves an aim and go for it whatever the consequences are. In fact, this nautical journey is not a personal matter since it is not only about killing the whale. Joseph Conrad highly evaluates the subject Captain Ahab's journey is set for. He describes the nautical journey as "a rather strained rhapsody with whaling for a subject and not a single sincere line" (Cotkin, Dive Deeper 8). Therefore, the journey is to bring the lost pride and dignity, assert Man's significance, uncover the secrets of the universe, and attain hidden truth that lies there in the depth of the ocean. This kind of hidden truth is not found everywhere but there in the depth of the sea which has "sweet mystery ... whose gently awful stirrings seem to speak of some hidden soul beneath" (Melville 384).

Man, of course, has limited knowledge, but it is essential not to forget that she/he has positive attributes such as power, determination, and over-confidence. In order to make this limited knowledge unlimited, it is indispensable to unleash the unlimited great human attributes against the limited forces of nature. Unleashing the human attributes would foreground humans to all tangible objects. Likewise, Captain Ahab never gets away from the whale. There are three days in which the crew confront the huge whale. Ordinary and not daring people would surrender and withdraw from the beginning of the first chase after Moby-Dick in order to escape the danger of the gigantic whale. Ignoring and belittling everyone, Captain Ahab never hubristically makes The Pequod sail away because his effective hubris pushes him forward rather than backward. He fully recognizes that he 
will neither encounter Moby-Dick by chance nor will Moby-Dick come to him. Instead, such a magnificent whale never willingly comes but is proudly and tenaciously pursued. Although the captain recognizes that he is physically weak because of his leg, he contemplates his poor situation, saying: "Here I am, proud as Greek god ... I would be free as air". The captain wants to cram all the hardships of his journey to one left leg, saying "By heavens! I'll get a crucible, and into it, and dissolve myself down to one small, compendious vertebra" (Melville 376-77). Therefore, Captain Ahab discards reluctance, sloth, and fear from his mental dictionary, but he shelters other qualities such as determination, self-esteem, and overconfidence to help him in his pursuit. Therefore, without the hubristically willful and indomitable spirit of Captain Ahab, the ecstasy of truth will not be attained.

Fedallah $^{12}$ declares that Captain Ahab has two prophecies, and he will be killed by a rope lashed to his body. What is important here is that Captain Ahab ignores all prophecies and omens because he blindly believes in the significance of Man in changing the course of life. Therefore, all incidents foreshadow that the doom of The Pequod is inescapable, but the heroic actions of the hubristic captain intervene to make it escapable. Captain Ahab never believes in prophecies, omens, or luck but in one thing which is himself. Ignoring prophecies and omens is not necessarily unacceptable. Being skeptic may be sometimes functional, and this is what makes Skinner say that "the skeptic believes nothing, and is not deceived by false prophets" (4). His taken leg by Moby-Dick in one of the whaling journeys and his scarred face cram and summarize all meanings of experience, skillfulness, and resourcefulness as a whaler. The more he gets far away from the whale, the more his hubris necessitates closeness. That is why he tries to investigate more and more and come too close to Moby-Dick to bring his lost pride back. That is why he capitalizes on the human attributes that can function as an effective blow to the forces of nature. These human attributes that Captain Ahab capitalizes on "express an excess of purpose, a hunger for self-enhancement, in which every thing and every other human being is instrumentalized for [Captain] Ahab's personal ambitions" (Fluck 209). He hubristically jumps on the whale, considering the whale as the incarnation of knowledge and truth because this white huge body which is full of mysteries and knowledge proves Captain Ahab's over-confidence and self-esteem, for he is over all the elements and tangible objects of nature. It is true that Captain Ahab dies out of the severe confrontation

${ }^{r} \mathrm{He}$ is one of the important whalers and master harpooners of the ship. He sails with Captain Ahab to help him kill the whale. 
with the whale, but he is not defeated because such a heroic deed found in very few people functions as an act of victory rather than defeat.

Captain Ahab always tries to appear on the deck of the ship where the place of leaders is. Only after the giant whale emerges does Captain Ahab leave that place. He jumps on the whale to pin him down; he does not get afraid like the other crew who try to relatively withdraw. Even when he is lashed to his body harpooning him, he never gets afraid even to the last moment. He never gives up, and this is an act of victory since he never surrenders to the forces of nature, particularly to a leviathan. Melville presents Captain Ahab as a different leader and whaler and gives his presence an aura of dominance that makes others enthusiastically watch and attentively listen to him. He appears on the deck as a sultan of the ship, and this "certain sultanism of his brain, which had otherwise in a good degree remained unmanifested," (Melville 125). Melville dedicates a whole chapter entitled 'Ahab' through which he gives him a heroic stature, describing him that there is "an infinity of firmest fortitude, a determinate, unsurrenderable wilfulness, in the fixed and fearless, forward dedication of that glance" (107). In fact, Captain Ahab firmly believes that it is "craven" to "crawl to land" because this is "terrors of the terrible!" (95). His effective hubris opens the door wide for other human attributes such as determination, over- confidence, tenacity, and courage to assert themselves against the forces of nature. $\mathrm{He}$ is put in a situation that his effective hubris becomes unable to make a compromise with the forces of nature symbolized by MobyDick. Had he compromised, he would have lost not only his pride and dignity but also himself. This part in his personality as being insistent and persistent for achieving his ambition makes Jony Kushner say that the "part of what makes him great is his immense ambition" (Cotkin, Dive Deeper 11).

Ishmael is the narrator of the heroic story of Captain Ahab and the crew. He, including the other crew in the final scene when confronting with the whale, represents the choice of the norms who prefer to secure their bodies and continue living safely. That is why he tends to stay alive securing his body from danger and more importantly death. On the other hand, the industrious Captain Ahab monomaniacally chooses, out of his effective hubris, a daring method in dealing with tangible objects, underestimating everything outside himself. He stays fearless through the course of the nautical quest and ignores all omens and warnings by others based on possibilities. "For the stoic and fatalist Ishmael, the world provides welcome material for his games of imaginary expansion, for the Faustian quester [Captain] Ahab it becomes a tantalizing provocation to which he responds with 
fits of monomania and rage" (Fluck 209). His damaged pride and dignity by the whale make him sometimes behave maniacally and stay in a state of disequilibrium since he hubristically "would strike the sun if it insulted [him]" (Melville 139). Such over-confidence and hubris make him believe that he can change the course of events and natural phenomena. In addition, this blasphemy may force Melville to bring Captain Ahab to his death. However, it seems unfair not to admit that such over-confidence and hubris make him effective, inspiring, and charismatic and force the crew to listen attentively and follow him blindly. His crew hesitantly face with him the blackness of darkness on the sea, fearing of everything unpredicted because their purpose is of material one. Although they well know that it is dangerous to follow him, they try to shelter themselves under his commands and effective presence. His charismatic personality leaves no room for them to be reluctant, but it makes them follow him blindly and willingly. Starbuck expresses fear of Captain Ahab's monomaniacal chase after Moby-Dick, but he is unable to show his disobedience saying:

My soul is more than matched; she's overmanned; and by a madman! Insufferable sting, that sanity should ground arms on such a field! But he drilled deep down, and blasted all my reason out of me! I think I see his impious end; but feel that I must help him to it. Will I, nill I, the ineffable thing has tied me to him; tows me with a cable I have no knife to cut. Horrible old man! Who's over him. (Melville 142)

The attitude of Starbuck and the crew in general makes C.L.R. James astonished through asking the question: "Why didn't the men revolt?" (Cotkin, Dive Deeper 10) against Captain Ahab since he seemingly leads them to death. This ineffable thing, in fact, that Starbuck feels it ties him with Captain Ahab is the captain's charismatic sense of leadership, courage, daring steps, imperiousness, and effective hubris. If Starbuck dares to cut that cable which ties him with Captain Ahab, he along with the crew will be destroyed and lost on the sea. That is why Captain Ahab's daring steps and courage transform the crew's fear into courage. The crew's motive towards Moby-Dick is unlike Captain Ahab's. Captain Ahab's inner nature considers the whale as a spiritual destination full of mysteries that should be uncovered at whatever cost. This kind of comparison between Starbuck and Captain Ahab is to subtly elevate the latter to the former. Captain Ahab's behavior is not easily understood by the crew because he looks for something the crew have no idea about, which is high truth incarnated in Moby-Dick. Spark says:

Ahab/Melville reproach[es] Starbuck's philistinism, telling him to 'hark' below the surface of the statement, as Ahab and other modern artists marshal analytic skills to discover the truth and to 
know themselves. [Captain] Ahab's speech is a call to revolution against illegitimate authority, but also a challenge to sincerely Christian readers harkening to Father Mapple's higher law. (311)

Melville's implied comparison between Captain Ahab and Ishmael manifests how the latter who tries to stay alive represents the religious way of viewing the universe. Therefore, he is "a religious hero". Ishmael admires the do-or-die attitude Captain Ahab has because Ishmael is void of such human attributes which he is unable to possess. However, by being effectively hubristic, over-confident, challenging, and blasphemous, Captain Ahab sounds to "wield religious authority", and that is why he is, unlike Ishmael, classified as "a negative religious hero" (Ramachandra 25). Such a negative religious hero remains mentally unstable to the extent that he gathers all his greatness and positive attributes and unfolds them when confronting with Moby-Dick, resulting in a tragically heroic confrontation which ordinary whalers are reluctant to involve themselves in.

The whale, for the crew, is a kind of material achievement. They run after him to process his oil and get benefit from his flesh. However, Captain Ahab's purpose of the journey towards the whale is completely the opposite. The whale is obscure and full of ultimate truth and knowledge; it is indispensable for humans to penetrate, attain, unveil, and more importantly avail from. Such ultimate truth is never reluctantly unveiled or availed from. Only when the great human attributes are unleashed does the ultimate truth become accessible to humans. Such truth, symbolized by Moby-Dick, is there having an aura of mysteries and seductions in the depth of the ocean rising and diving. This mysterious truth strongly attracts Captain Ahab's soul to dive, strike, and pluck from the heart of the ocean. "No man can deny that in its profoundest idealized significance it calls up a peculiar apparition to the soul" (Melville 161). That captain is crazy about having absolute power. Such power is, to Captain Ahab, found only in Moby-Dick. This power challenges, defies, and impedes the power of Captain Ahab which he refuses to accept or even make a compromise with. He quests defying all elements of nature except for himself, aspiring to place himself on the peak. He recognizes that there should be no room for submission with such nature that is subject to rules and laws which are used by humans only. He appears as a man who is hubristically enthusiastic to elevate himself although he well recognizes that "self-enhancement and self-deconstruction are thus closely related and constantly feed into each other" (Fluck 209). This incredibly unbelievable individuality propels Captain Ahab to end his private battle by himself, and this is the real characteristic of real men and the precise meaning of manhood. This actually brings to 
the mind Tagore's idea about the hero when he says: "not to ask for relieving my pain, but to be able to tolerate it; not to wait an ally in the battle of life, but to wait the support of my strength only; not to beseech in strict horror for the sake of safety, but to enjoy tolerance until I reach my freedom" (105).

Defiance is always there in the behavior of Captain Ahab. He defies every authority he encounters in his way. He defies the natural power with a powerful and indomitable spirit that believes in the possibilities of death rather than in the possibilities of defeat. His defiance to everything and his over-confidence make him respectable because his shipmates view him as a high authority. He heroically recognizes that he should not lose the battle with Moby-Dick. Losing it would deprive him of his excessive pride; winning it, on the other hand, would cause his death. This drives Ziff to admire Captain Ahab's faith in himself, saying that it has a "capacity to survive the oppression of social institutions and challenge the difference of natural forces" (xiii). Therefore, surrender to the forces of nature never crosses his mind because he knows that he is going to die either ways. He remains strong, persistent, stable, but never shaken by the magnitude of the whale. He well knows that once the human pride is taken from him, there will be no compromise with nature. He either should go and bring it back or die since he will never rise again if he withdraws or surrenders to the challenges of nature. Accordingly, Captain Ahab flashes as a greatly unique hero who hubristically elevates himself to a degree the other crew are unable to see or recognize. He is now a hero of a noble purpose, proving his identity, as a great captain and whaler, with one leg. Moreover, he is a man who is different from others that chases the unobtrusive truth, knowledge, and evil, incarnated in Moby-Dick, which are found in the heart of darkness and more importantly in the heart of hardships and suffering through questing after the whale. This leads Lowry Nelson, Jr. after analyzing Captain Ahab's actions to conclude that Captain "Ahab's pursuit after the whale ... is both a search for significant evil and for his own identity" (Cotkin, Dive Deeper 11). Melville here artistically succeeds in creating such a uniquely hubristic character full of strangeness since he focuses on "literary ambition and appetite for imaginary self-expansion" (Fluck 208) which begin to grow in the $18^{\text {th }}$ century. However, although this character is full of strangeness, he is greatly liked and to some extent welcomed by the crew and also by readers and critics. This is actually what makes Van Wyck Brooks unable to help himself stop elaborating about Captain Ahab saying, "Of Captain Ahab I should never stop talking if I once began" (Cotkin, Dive Deeper 9). 
Duty has multiple connotations in the course of the incidents. Starbuck appears faithful to others. He pays homage to God and to Captain Ahab. Although he is not sometimes satisfied with Captain Ahab's decisions, he always informs him of what newly happens on the ship. When he sees that some barrels of whale oil leak, he immediately informs Captain Ahab. Captain Ahab, in such a situation, is supposed to stop the ship and start fixing the problem because this is, for the crew, what they seek. They should secure the whale oil to bring it back ashore and make use of it. Starbuck says to Captain Ahab, "What we come twenty thousand miles to get is worth saving, sir". Of course, Starbuck says this, referring to the whale oil that is in the barrels. However, Captain Ahab responds, "So it is, so it is; if we get it" (Melville 378). Here Captain Ahab means Moby-Dick not his oil or profit nor the leaking barrels. Therefore, his quest is not for material purposes but is for spiritual ones since he does not care about the oil splashing on the ship. He does not order the crew to stop the ship to fix the problem. Accordingly, Captain Ahab's duty is different from Starbuck's. The former's duty is only for himself and to assert his existence and achieve the aim he looks for. Cotkin compares between the two in the light of existentialism. He says: "to very Starbuck in American culture who comes to hunt whales only for material gain, there is the existential thrust of an Ahab who berates Starbuck's refusal to contemplate 'a little lower level' of existence" (Existential America 8). The captain defies all kinds of duties except for that of restoring his lost pride and dignity back. Being a charismatic leader, Captain Ahab succeeds in attaining and retaining the crew's duty from the beginning of his quest to the end. His passions propel him blindly to underestimate everything even the sun and the wind. He resents the wind which is "coward wind that strikes stark naked men but will not stand to receive a single blow" (Melville 443). Melville here foregrounds the captain to others as an inquiringly existential one where all his "means are sane" and his "motive and ... object [are] mad". Melville asserts that Captain Ahab "to mankind, did long dissemble ... [and] so well did he succeed in that dissembling" (156). This kind of weird and hidden desires and thoughts towards the indifferent world makes Albert Camus comment on this, saying that Captain Ahab "recognized the absurd nature of existence - the deep distance between our desires and tricks played upon them by an indifferent reality" (Cotkin, Dive Deeper 16). The hero who is not stereotypical is uniquely made to advocate the human passions and significance over nature. Fluck here describes the invention of Captain Ahab's character to be as a modern hero rather than a stereotypical one full of great qualities: 
Moby-Dick is a novel that defies classification because it is in a state of constant proliferation not only on the paradigmatic level of metaphorical extension but also on the level of syntagmatic linkage and in its wealth of intertextual references. For a modernist reading, such defiance realizes an inherent potential of art to oppose cultural convention. Quite obviously, however, there are historically different and changing forms of how conventions can be subverted. (211)

Whaling is a challenging task for the crew and Captain Ahab. It needs physical and mental abilities. Hunting a whale, for the crew, may or may not always happen. However, for Captain Ahab, there is no room for possibilities in catching the whale because the whale does not represent material achievements but spiritual ones. If Captain Ahab does not catch the whale, he will be spiritually a dead man. The crew take possibilities into consideration that they may not catch the whale. That is why they are fueled by Captain Ahab's weird desire and effective hubris to kill that whale. The captain's aura of inspiration and effective hubris hover above the ship, propelling the crew forward all the time. It seems that once his role is absent, sloth and reluctance would hover above the ship. His presence in the ship fuels the men with strength since Captain Ahab is a great leader whose "leadership is about creating an alignment of strength-making people's weakness irrelevant" (Garner 33). It is Captain Ahab who is able to lead the Pequod alone and who knows that "the essence of leadership is the capacity to build and develop the self-esteem of the workers" (37). Captain Ahab's journey is full of danger, struggle, challenge, and hardships that sometimes seem stronger than he is. This makes him a menacing and invincible hero enduring such challenges and hardships. He remains a hero that becomes an epitome of courage for others. When confronting with Moby-Dick which results in Captain Ahab's death, he suffers only from without not from within. He spiritually satisfies his thirst for bringing Moby-Dick down, but Moby-Dick overcomes him physically not spiritually. Therefore, he hubristically defies accepting surrender to Moby-Dick or staying tormented in a world of humiliation after his pride is taken from him by Moby-Dick. This compels Engel to describe Captain Ahab as "a titanic figure, whose intellect and will-power make a natural leader" (105). This leader seeks infinity which hides itself there in the depth of the ocean because "the sea had jeeringly kept his finite body up, but drowned the infinite of his soul" (Melville 334). Because the sea hides its secrets in its depth, Melville admits that he "love[s] men who dive" (Cotkin, Dive Deeper 5), elevating the hubristic Captain Ahab and making him dive into the profound ocean to his death. Therefore, the battle on the sea is not an easy one; it is full of challenges, danger, and infinity. This infinity Captain Ahab searches for causes his death since 
it "carried down alive to wondrous depths" (Melville 334), and this is what makes his quest a noble one.

The concept of fate in the course of events on the sea is refused by Captain Ahab. Captain Ahab says that he is the "Fate's lieutenant" (Melville 442). This phrase epitomizes his over-confidence and effective hubris that keep him influential among the crew who recognize that he has the capacity to change the course of events as a great captain. Starbuck thinks that it is "blasphemous" to take revenge "on a dumb brute ... that simply smote thee from blindest instinct!" (138). Moby-Dick is a gigantic whale that cuts Captain Boomer's arm and Captain Ahab's leg. It is depicted as an animal which is too dangerous to run after. Each one in the novel considers the whale as something different, and this actually reflects how people look at life differently. Some avoid him; others pursue him. Stubb whispers that the whale "smites his chest" and this means nothing for him because although the whale "rings vastest," it seems "hollow" (138). Captain Ahab's ideas about the whale are not clearly shown but understood. For example, Ishmael thinks that Captain Ahab views the whale as the embodiment of evil. In fact, it seems that Ishmael is not confident whether the whale represents for Captain Ahab something evil or not. Melville himself is ambivalent in manifesting the significance of the whale in the chapter entitled "The Whiteness of the Whale". This whiteness delivers the meaning of good. At other times, it delivers the meaning of evil since the whale severs Captain Ahab's leg and Captain Boomer's arm. It seems something glorious; at other times, it is the symbol of determination and humiliation. D. H. Lawrence has an idea about the meaning of the whale that "he is the deepest bloodbeing of the white race" (Cotkin, Dive Deeper 8). Cotkin argues that "the meaning of such confrontations with the abyss is that there is nothing there, other than the horror of nothingness. The Whiteness of the Whale blinds us to the blackness of being" (242). Melville's ambivalence about the exact meaning of the whale drives Van Wyck Brooks to say that "he is fate ... and Captain Ahab is the tragic will of man which defies it and tracks it down, only to be overwhelmed and to perish by it" (Cotkin, Dive Deeper 8). In fact, the symbol of the whale does not too much matter because what really matters is Captain Ahab's way and technique of pursuit after the whale. This pursuit elevates him to the peak of glory because he considers all visible objects particularly the whale "as pasteboard masks" ${ }^{13}$. But in each event - in the living act, the undoubted deed-there, some unknown but still reasoning thing puts forth the mouldings of its

\footnotetext{
' According to Captain Ahab, all visible and tangible objects are pasteboard masks, so they had better be penetrated to reach the obscure and the unknown. Accordingly, Moby-Dick is a thick
} 
features from behind the unreasoning mask" (Melville 138). These masks for Captain Ahab are knowledge, ultimate truth, and secrets, so "if man will strike, [he] strike[s] through the mask! How can the prisoner reach outside except by thrusting through the wall?" To Captain Ahab, "the white whale is that wall, shoved near to [him]" (138). Captain Ahab's effective hubris is restless until it is sated with "Truth [that] hath no confines" (139). This truth seems unattainable because it is hidden behind an "outrageous strength, with an inscrutable malice sinewing it" (138). Captain Ahab's effective hubris and dignity require that such an inscrutable malice be completely uncovered and necessarily known.

Captain Ahab's observation of the whale is of great importance that is found in few people only. He views Moby-Dick as a great agent behind it exist an effective power, an aura of mystery, and more importantly illegitimate authority ${ }^{14}$. Captain Ahab's effective hubris is still unresolved if such power and illegitimate authority remain invisible or ungraspable. This actually leads Spark to admire Captain Ahab's ambition and excessive pride, saying that "universal standards of morality were enlisted in the service of amelioration and democratic self-management, energizing resistance to all forms of illegitimate authority. Such objectives would be stigmatized as effluents of [Captain] Ahab's ambition and pride" (12). He likens the body of the whale to a prison wall. The prisoner should strike against the wall of the prison, symbolized by Moby-Dick, in order to reach the light and truth that lie behind which humans spend their lives searching for. Therefore, Moby-Dick is not a facilitator but a hindrance since he, to Captain Ahab, "becomes more than just a brute animal: he is the symbol of all that consciously attempts to limit, destroy and subjugate man" (Hamad 31). Therefore, this human passion, for Captain Ahab, of searching, questing, unveiling, and bringing down what restricts human beings' abilities should be unleashed. This quest for the dangerous and the unknown is not found in every human being but rather in great ones such as Captain Ahab who strives for striking in the unknown and mysterious, and this is in itself courage. Because Captain Ahab "consciously", as proposed by Hamad, recognizes what restricts him and his goal, such goal cannot be described as a mad or a dangerous one; instead, it is a noble one, willingly pursued rather than unconsciously pushed for. Furthermore, it is Captain Ahab's dignity and effective hubris that make him go and investigate this mysterious universe which is full of secrets heedless of

\footnotetext{
' Captain Ahab thinks of Moby-Dick as an "illegitimate authority". The whale has an authority since he is enormous and great, and he is "illegitimate" because Captain Ahab thinks that there is no authority compared to the authority and power of Man. Because such an authority stems from a leviathan, it is absolutely illegitimate.
} 
the results. Such quest and effective hubris make him enthusiastic to fulfill his aim. Captain Ahab's strange behavior gives a hint to Hamad that his "overpowering pride leads him to believe that he is, in fact, superior to the forces of nature" where he "demonstrates his defiance to nature when he refuses to depend on the sun for help in navigating" (Hamad 31-32). In fact, Captain Ahab sees all tangible objects from his point of view, refusing any consultation from others. In fact, this kind of individuality, without any doubt, puts him on the peak of glory. Because he behaves monomaniacally and believes blindly in his ability and judgment as a Captain, which is found only in unique people, this compels Hamad to finally admit of the possibilities of being a great hero saying that Captain "Ahab's vision may be mad but the intensity of his defiance and his unyielding courage to assert man's significance in the universe give him heroic stature" (31).

Human beings are eventually all mortal, and the Pequod's journey on the sea is similar to the journey of people in life. It sets from immaturity and endures the forces of life to reach maturation. Captain Ahab "hungers ... for a deeper penetration of the meaning of life" (Cotkin, Dive Deeper 242). The ship is destroyed at the end of the novel, and the crew bring no whale oil with them. They are all dead except for the narrator, Ishmael. Therefore, is maturation attained at the end? In fact, the matter is not actually with death but in the way towards death. Accordingly, humans make their fate by their own hands. Moreover, they are fated to endure and struggle and give and take. That is why Captain Ahab seems right when he says that he is the "Fate's lieutenant". In other words, he is able to change the course of events in opposition to what the prophecies declare since he knows what a man can do. It is Captain Ahab who chooses his death in a scene full of heroism that gives an inspiring hint to readers to follow his heroic stature because his speech always sounds defying to everything that "tasks" and "heaps" him (Melville 138).

Effective hubris is the spark for determination and courage and other unique human qualities. When Captain Ahab takes the resolute decision, he already knows that he is fated to die. When the crew confront the whale, that takes three-day encounters. In the first day, Captain Ahab sights the whale and then launches a pursuit, but the result is that the whale cuts his boat into two pieces throwing him out of it. On the second day, Captain Ahab again is destroyed physically by the whale since the whale destroys the boats, pushing the crew to retreat. Captain Ahab is rescued, but his leg that is made of ivory is taken again. In fact, the more Captain Ahab seems to be defeated and beaten, the more he becomes hubristically insistent to continue. Starbuck pleads with Captain Ahab to stop and withdraw from killing the whale. However, this seems insulting to Captain Ahab's tenacious 
spirit because his consideration is not restored until the whale is dead. "This obsession about killing Moby-Dick is clearly an encroaching madness. As [Captain] Ahab gets closer and closer to the prey, his madness increases" (Engel 69-70). In fact, pride is a precious human quality that can bring humans down if it is shaken. His strange pursuit motivates others and keeps them away from the routine of life and reality. Such fatal hubris seems to be his triumph and disaster at the same time. In other words, he is physically destroyed but spiritually triumphant. Such a strange quest after the whale is not of an individual's attempt for personal revenge. Instead, it is Man's strong attempt to establish self-esteem and dignity of mankind while confronting negative forces and challenges of life, and this is in itself heroism. This actually corresponds to John Lash's viewpoint, in Catherine Holder Spude's book, about the concept of the hero saying: "In excelling and exceeding himself, the hero becomes a model of higher potential for his clan, his nation, and even for humanity at large" (Spude 198). At the end of the second confrontation with the whale, the torment of Captain Ahab conquers him from within and from without; that is why he hubristically tries again to attack MobyDick. He rejects to surrender to a brute animal or stay tormented in the loss of his hubris and dignity. He sacrifices himself for his dignity, reputation, and hubris. His hubris takes his body, which is lashed to the huge body of Moby-Dick, down to the lap of the ocean to drown. Therefore, Captain Ahab's unique "passion, not his intellect, triumphs in the end" (Engel 88).

In brief, Captain Ahab listens to the voice of his passions such as hubris, dignity, and domination. However, his hubris does not allow him to overlook his dignity and reputation or relinquish his principles and standards as a great sea-captain who is supposed to be daring, courageous, determined, and tenacious. Accordingly, having analyzed and explored the actions and thoughts of Captain Ahab throughout the course of his sea-journey, the observations of this paper conclude with the following:

First, Captain Ahab's effective hubris is the valve for determination, strength, courage, persistence, ambition, and tenacity. Without his excessive pride, he would not be what he is as a greatly inspiring hero. He hubristically recognizes that determination and boldness are effective weapons in achieving a goal. Accordingly, there is nothing withstanding Man's power, so Man has to try and go forward whatever the results are since human beings are all mortal; they are eventually fated to die because this is inescapable. However, to die in bed while sleeping comfortably and peacefully is completely different from dying there in the battlefield and in the lap of the ocean, struggling and challenging heroically the forces of nature. In other 
words, to have a noble cause to struggle and die for is completely different from dying while sleeping in bed. Captain Ahab's strong desire to restore the human precious dignity and consideration that are taken from him keeps him full of energy from the beginning of the quest till the end. His vision of the whale is far away from taking revenge. In his philosophy, he should quest here and there for unlimited truth and never look askance at his abilities. This truth and knowledge should be attained and deciphered whatever the cost is. Archibald MacLeish suggests that "Moby-Dick has the kind of truth few men are able to put in words" (Cotkin, Dive Deeper 9). Although the Captain's hubris takes him far away causing his death, it is important not to forget that he courageously and fearlessly quests for such truth incarnated not only in an ordinary whale but in a huge one that causes phobia for other whalers and captains. This phobia about Moby-Dick makes Ishmael, the only survivor, narrate the heroic actions of Captain Ahab against the huge whale in a way that "seat[s] [him] sultanically among the moons of Saturn" (Melville 372).

Second, Captain Ahab's death delivers a lesson to humanity that Man is the only supreme power in this universe. The captain's effective hubris and over-determination always form a barrier for external nature which always tries to keep its secrets hidden behind thick masks. He courageously strikes those masks that cover the mysteries of the universe embodied in his sea-journey. Furthermore, he overcomes the obstacles whether they reside in the outer nature or in the human one. Moreover, he pursues the whale to pin him down since he is the embodiment of everything that restricts Man. Accordingly, propelled by the instinct of domination, the captain's pursuit is to break and destroy everything in life such as customs, traditions, dogmas, and all kinds of bounds that are imposed on humans in order to reach freedom. In fact, he appears "proud as Greek god" because he "would be free as air" (Melville 376). This kind of instinct in Captain Ahab, although it takes him too far towards his death, deserves admiration since he respects his instinct and remains faithful to it regardless of the consequences.

Third, humans are born with great attributes that beautify and dignify their lives and make them colorful. Captain Ahab's quest is a noble one since he refuses to live an ordinary life. He understands that without having his lost pride, dignity, and reputation taken by MobyDick back, he will be psychologically tormented and spiritually dead. Accordingly, his effective hubris makes him dare to put his feet in a place no one not only dares to but never dares to think of. What dignifies Captain Ahab is that he fearlessly puts his feet in danger. However, what makes his quest noble is that the dangerous place which he is in is his profession, and this is in itself nobility where 
Captain Ahab's cut leg and the "crucifixion in his face" (Melville 107) cram all the toil and the difficulties of being a whaler. Moreover, his effective hubris in dealing with internal human nature and external one sounds strange but greatly unexpected and unexpectedly great. It hinders him from retreating from the calamities of nature and forces him to have a do-or-die attitude whatever the results are, delivering a message that Captain Ahab may be destroyed from without rather than from within.

Fourth, the unresolved struggle and battle of the human nature with the external nature rise and fall and will always rise and fall forever, and finally many humans' attempts to make the unresolved resolved, the unsolved solved, and the unanswered answered would seemingly remain continuous and never-ending as long as external nature and Man clash with each other. The clash of Captain Ahab generates knowledge although it leads to destruction. This actually meets with Hamad's notion about the external nature symbolized by the sea when he says that "the sea threatens drowning and extinction $\ldots$ and provides the opportunity for ritual immersion and rebirth .... Because the experience is often terrible and almost always altering, the questers return from trial at sea to the harmony of their social contexts enlightened with transforming knowledge" (7). This transforming knowledge is transformed by Ishmael to all humanity that humans should excessively pride themselves on positives they have such as dauntlessness, determination, courage, daring steps, and tenacity. Upon having these qualities, there is nothing impossible in life. Humans should set an aim and quest for it. "Wherever it leads, it leads further and deeper into life; even though the quest pattern comes full circle, it reaches a dead end" (6). Therefore, what matters in life is not the dead end; instead, it is questing further and deeper in life for more truths, lurking somewhere behind some masks. This quest should be an important project. Captain Ahab is indulged in a hubristically risky nautical project full of amazingly over-confidence and effective hubris, making him a titanic figure. "When it conceived it was a project of almost unimaginable boldness ..., requiring great bravura, risking great hubris" (Winchester 103). There is no doubt that his unimaginable boldness, bravura, over-confidence, determination, courage, tenacity, individuality, and willful and indomitable spirit would spring from nothingness but from certainty and effective hubris. Therefore, humans should "never underestimate the appeal of certainty —or the propensity of hubris" (Rose ${ }^{15}$ ). His effective hubris,

\footnotetext{
' Frank Rose is an author, a journalist and a keynote speaker. He is the author of The Art of Immersion. He always publishes articles in the two famous American Journals, The Wall Street Journal and The New York Times. For more information about this article which encourages the appeal for certainty and propensity of hubris, visit this link of The Wall Street Journal:
} 
certainty, and over-confidence are never found wanting through his nautical journey since they stand for a womb, sheltering him from surrendering to the external nature and the internal human one. Accordingly, this certainty, tendency for hubris, and over-confidence take Captain Ahab from the abyss of humiliation to the peak of dignity and place him honorably on the summit of glory.

Finally, hubris, knowledge, reputation, self-assertion, and truth are precious for the captain, and they need something precious in return even if it is his life. Captain Ahab dies as a martyr for his dignity, hubris, reputation, knowledge, and truth of the universe trying "to popularize profundities [because] all truth is profound" (Melville 55). It is true that Captain Ahab's hubris drives him to his death. However, it drives him to fight a tremendously great whale, which the other captains never dare to fight, so he fights the great, and fighting the great is in itself greatness even though it leads to death. In fact, Captain Ahab's heroism comes from the fact that he does not die in bed but there in the lap of the sea which, as Joseph Conrad describes, "was a stage, where was displayed an exhibition of valour" (4•-41). In the last confrontation with the whale, Captain Ahab fearlessly jumps on his body harpooning him when Moby-Dick rises above the surface of water. The captain is stuck in the ropes that are lashed to the body of the whale. Then Moby-Dick dives into the depth of the ocean taking along with him Captain Ahab. The captain should be respected as a truth seeker where he dies, believing in the Melvillian principle that "in landlessness alone resides highest truth, shoreless, indefinite as God-so, better is it to perish in that howling infinite, than be ingloriously dashed upon the lee, even if that were safety! For wormlike, then, oh! who would craven crawl to land! Terrors of the terrible! is all this agony so vain? Take heart, take heart ... up from the spray of thy ocean-perishing--straight up, leaps thy apotheosis!" (Melville 95).

\section{Works Cited \\ Primary Sources}

Melville, Herman. Moby-Dick. New York: Dover Publications, Inc. 2003.

\section{Secondary Sources}

Bacon, Francis. The Works of Lord Bacon, Moral and Historical. London:

Warwick House, 1878.

Beiner, Ronald. Political Philosophy: What It is and Why It Matters. New

https://www.wsj.com/articles/the-age-of-surveillance-capitalism-review-the-new-big-brother11547509779. 
York: Cambridge University Press, 2014.

Chopin, Kate. The Awakening. New York: Dover,1993.

Conrad, Joseph. "Tales of the Sea." Modern English Essays. Vol. 4 Ed.

Ernest Rhys London: Dent, 1922.

Cotkin, George. Dive Deeper: Journeys with Moby-Dick. Oxford University

Press: New York, 2012.

---. Existential America. Baltimore: The Johns Hopkins University Press, 2003.

Engel, Wilson F. Notes on Moby-Dick. Essex: Longman, 1981.

Faulkner, William. Essays, Speeches and Public Letters. Ed. James B.

Meriwether. London: Chatto and Windus, 1967.

Fluck, Winfried. Cultures of Criticism: Herman Melville's Moby-Dick,

Expressive Individualism, and the New Historicism. Tubingen:

Gunter Narr Verlag, 1995.

Garner, Eric. The Art of Leadership. New York: Ventus Publishing Aps,

2012.

Hamad, A. "The Quest Pattern and Motif in American Sea-Novel." Journal

of Al Baath University 2 (1999). PP. 5-42.

Hemingway, Ernest. The Old Man and the Sea. Beirut: York Press, 2002.

High, Peter, B. An Outline of American Literature. New York:

Longman, 2003.

Isaacson, Walter. "The Real Leadership Lessons of Steve Jobs." Harvard

Business Review 120 (2012).

Khuon, Tony. "Personality Development for a Changing World: When

Hubris Is a Good Thing." Agile Life Style. Online Posting. March 6,

2014 <http://agilelifestyle.net/hubris-examples/>. It was retrieved on

$13 / 2 / 2018$.

Nietzsche, Fredric. The Will to Power. Trans. by Walter Kaufmann. New

York: Random House Inc., 1968.

Ramachandra, R. Melville and Conrad: A Comparative Study. Mysore:

Vasudha, 1983. 
Rose, Frank. "'The Age of Surveillance Capitalism' Review: The New Big

Brother". The Wall Street Journal, 14 Jan. 2019.

https://www.wsj.com/articles/the-age-of-surveillance-capitalismreview-the new-big-brother-11547509779. It was retrieved on $13 / 3 / 2019$.

Sadler-Smith, Eugene. Hubristic Leadership. London: SAGE Publications

Ltd, 2019.

Skinner, C. A. Miller Overthrown, Or the False Prophet Confounded. Boston, Abel Tompkins, 1840.

Spark, Clare, L. Hunting Captain Ahab Psychological Warfare and the

Melville Revival. Kent, Ohio: The Kent University Press, 2006. Spude, Catherine Holder. "The Friend in Hell": Soapy Smith in Legend.

Norman: The University of Oklahama Press, 2012.

Tagore, Rabindranath. Reaping the Fruits: A Vision into Tagore's World.

Beirut: Naufal, 2000.

Winchester, Simon. The Professor and the Madman: A Tale of Murder,

Insanity, and the Making of Oxford English Dictionary. Toronto:

HapperCollins Canada, 1999.

Ziff, Larzer. Introduction. Moby-Dick. By Herman Melville. London:

Campbell, 1991. 
الكبرياء وتأثيرها على شخصية كابتن إيهاب في رواية (الحوت الأبيض) لـ هيرمان ميلفل

$$
\begin{aligned}
& \text { اسم الباحث: عبدو إبراهيم جرجنازي }
\end{aligned}
$$

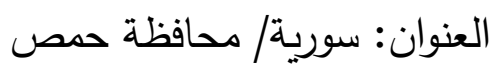

$$
\begin{aligned}
& \text { الصفة: مدرس في جامعتي البعث وحماه في سورية } \\
& \text { الاختصاص: ماجستير في الآداباقسم اللغة الإنكليزية }
\end{aligned}
$$

E-mail: abdo-edu@hotmail.com

Mobile Phone: 00963933366879

\section{Facebook: Abdo Jarjanazi}

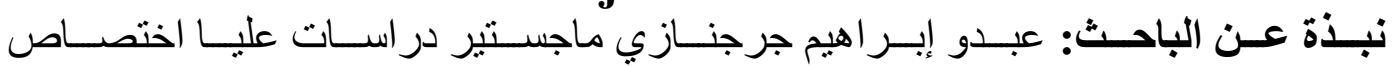

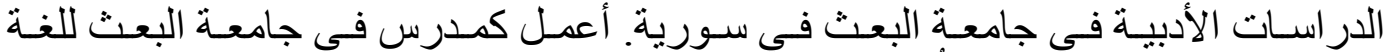

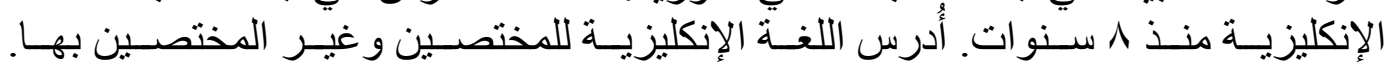

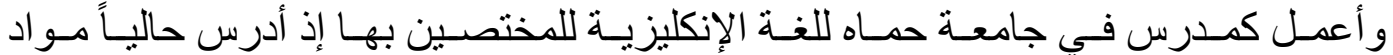

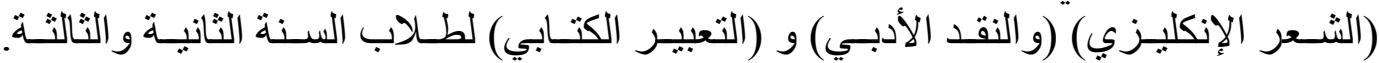

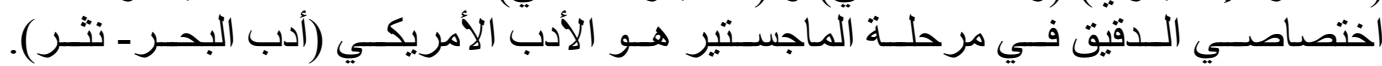

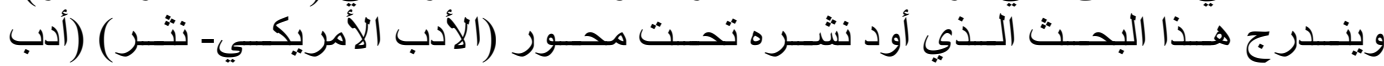

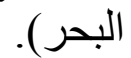
ملخص (النجر

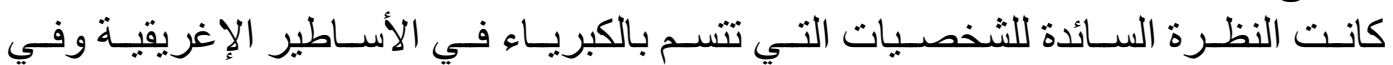

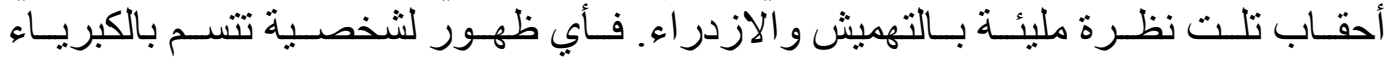

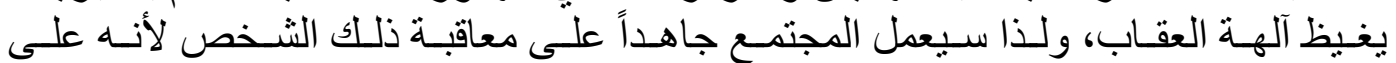

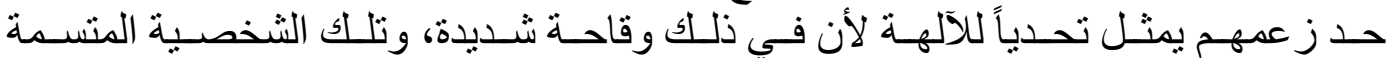

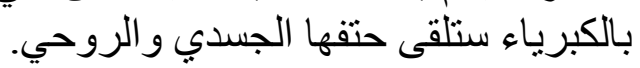

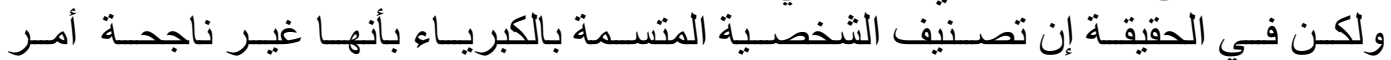

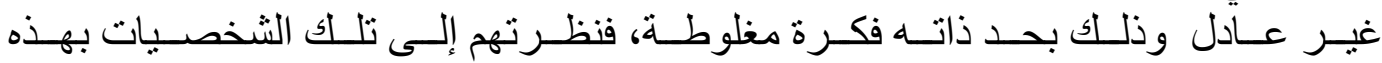

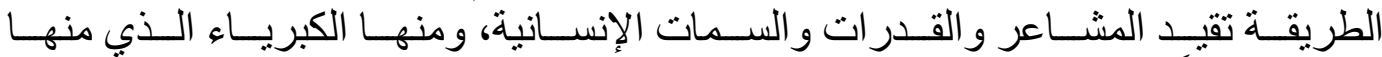

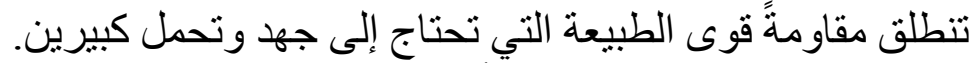

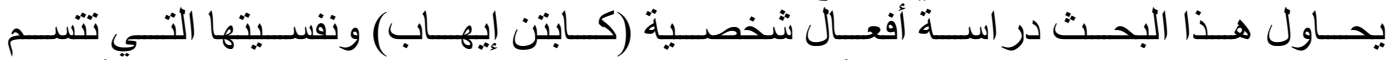

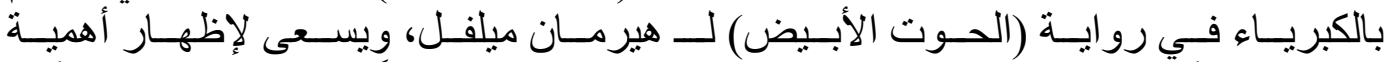

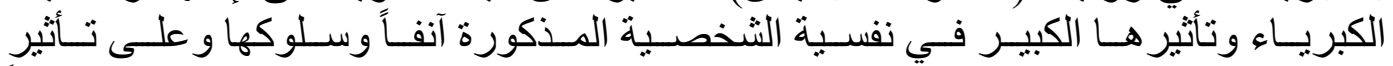

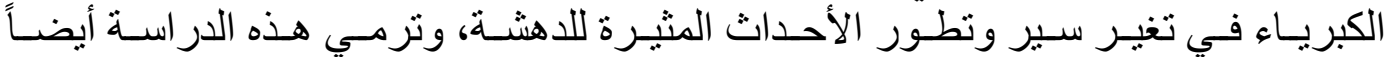

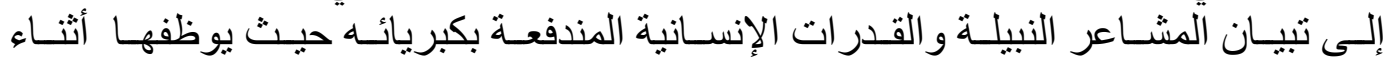

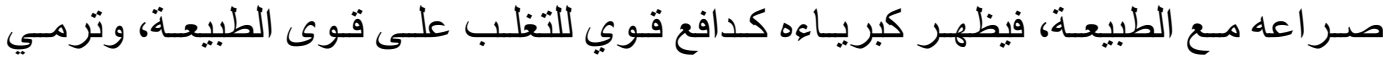

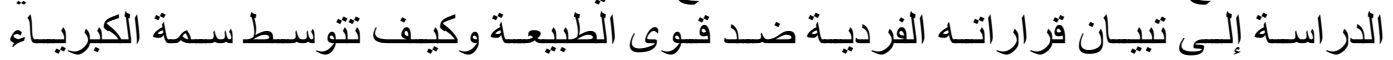

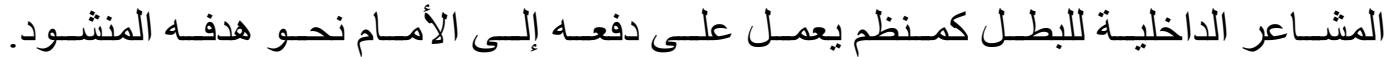

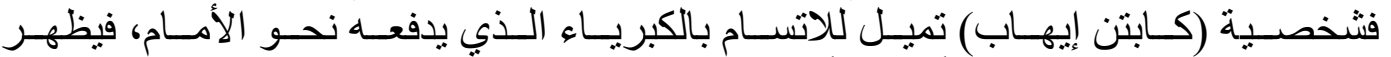

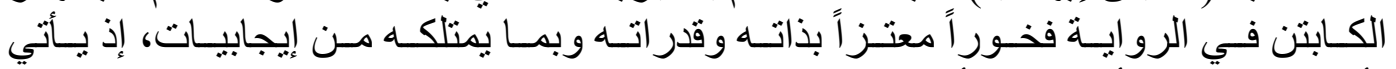

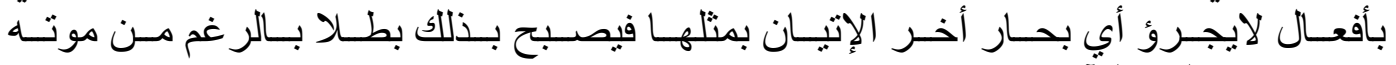

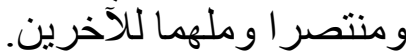
كلمات مفتاحية: الكبرياء_العزم ـالإصر ار ـ قوة الإر ادة 